\title{
Rapid Screening Assay for Ripe Rot Resistance in Grape Cultivars
}

\author{
Mikio Shiraishi*, Masahiko Yamada, Nobuhito Mitani, Toshihito Ueno, \\ Ryoji Nakaune and Masaaki Nakano \\ Department of Grape and Persimmon Research, National Institute of Fruit Tree Science, \\ Akitsu, Higashihiroshima 729-2494, Japan
}

\begin{abstract}
Ripe rot caused by Colletotrichum acutatum (CA) has been the most serious preharvest disease of grape berries/clusters. Furthermore, the pathogen is highly resistant to benomyl and iminoctadine-triacetate. A rapid assay for screening ripe rot (CA) resistance of breeding materials in table grapes was developed in which the harvested berries are washed with water and surface-sterilized in ethanol. The berries were then inoculated with conidial suspensions (ca. $3.0 \times 10^{5}$ spores $/ \mathrm{mL}$ per ten berries) in a polyethylene bag, and incubated at $25^{\circ} \mathrm{C}$ in the dark for 2 weeks. The percentage of diseased berries increased as the ripening of berries proceeded. A period of 70 to 80 days after full bloom was suitable for berry sampling and subsequent CA inoculation to evaluate varietal differences in the ripe rot resistance of grapevine.
\end{abstract}

Key Words: benomyl, Colletotrichum acutatum, grape, ripe rot, screening assay.

\section{Introduction}

Ripe rot has been the most serious preharvest disease of grape berries in Japan (Fukaya, 2001; Ozoe et al., 1972). Affected grape berries initially develop circular brown spots on the skin. The rotting berries are soon covered with salmon-colored masses of conidia (Fig. 1A). Frequent fungicidal applications are required to assure marketable and eating quality. Two pathogens, Glomerella cingulata and Colletotrichum acutatum (CA), are known as the causal agent. The latter fungus, $\mathrm{CA}$ is highly resistant to fungicides, such as benomyl (Sonoda and Pelosi, 1988) and iminoctadine-triacetate (Fukaya, 2002). Recently, dormant spraying near the time of bud break has been found to be less effective because of the insensitivity of CA to benomyl (Fukaya et al., 1998). The threat of fungal resistance to the control program makes the development of CA-resistant grape cultivars desirable. In this study we developed a rapid screening assay of ripe rot resistance to assist in table grape breeding.

\section{Materials and Methods}

Plant material was chosen based on a previous inoculation tests of grape ripe rot resistance at the Department of Grape and Persimmon Research, National Institute of Fruit Tree Science. The following cultivars were tested in 2004: 'Neo Muscat' (Susceptible; S), 'Sunny Rouge' (S), 'Campbell Early' (Resistant; R), 'Kyoho' (R), 'Yoho' (R). Fungicidal control in the

Received; June 22, 2005. Accepted; October 12, 2005.

* Corresponding author (E-mail: mikioshi@affrc.go.jp). experimental field was seasonally conducted until berry sampling.

CA was isolated as CAB03 from naturally infected berries and maintained them on potato dextrose agar (Niisui, Japan) at $25^{\circ} \mathrm{C}$ in the dark. The one-week old cultured $\mathrm{CAB} 03,1.4$ to $1.8 \times 10^{7}$ spores $/ \mathrm{mL}$ per petri dish $(90 \times 20 \mathrm{~mm})$ were stored at $4^{\circ} \mathrm{C}$ in the dark until berry inoculation (Fig. 1B). The CAB03 also could be stored at $4^{\circ} \mathrm{C}$ in the dark for two years or more and still remain infective.

Eight bunches in each cultivar were selected from which three healthy berries from the top, middle, and bottom per bunch (thinning about 35 berries) were collected at a 10-day interval from 30 days to 90 days after full bloom. The twenty berries were washed with tap water to remove surface fungicides, surface-sterilized in $70 \%$ ethanol for $30 \mathrm{~s}$, and rinsed immediately with sterile water. After being dried by kimtowel (Crecia, Japan), 10 berries were put in a polyethylene bag $(0.03 \times 260 \times 380 \mathrm{~mm})$. Conidial suspensions were

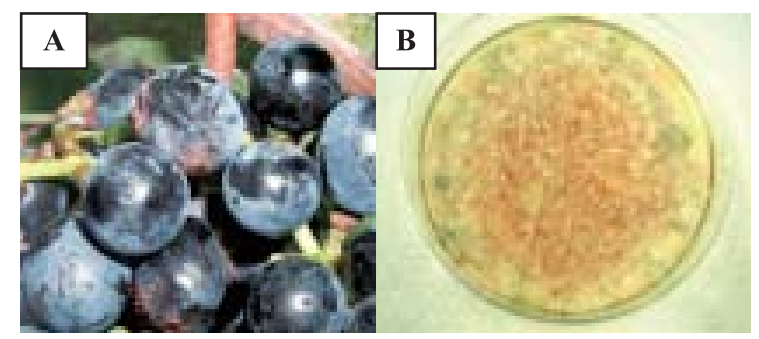

Fig. 1. Ripe rot symptom on naturally infected grape berries of 'Kai Noir', showing salmon-colored masses of conidia in the experiment field (A), and the 1-week old cultured isolates, CAB03 (B) 


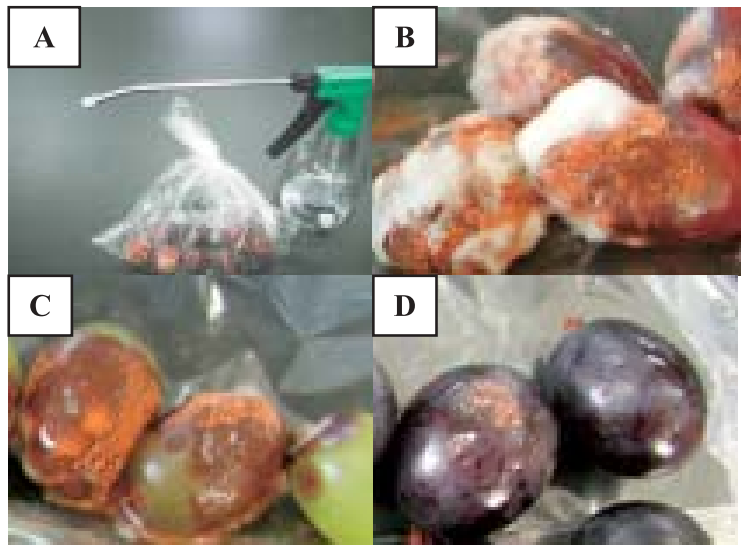

Fig. 2. An air brush sprayer with conidial suspensions of Colletotrichum acutatum (A), and infected grape berries of 'Sunny Rouge' (B), 'Neo Muscat' (C), and 'Kyoho' (D) resulting from the incubation at $25^{\circ} \mathrm{C}$ in the dark for 2 weeks after the inoculation.

scraped from the stored culture with $5 \mathrm{ml}$ of sterile water. The suspension was filtered through two layers of cheesecloth to separate mycelial debris from conidia and adjusted to $1 \times 10^{5}$ spores $/ \mathrm{mL}$ by using a hemacytometer (SUNLEAD GLASS, Japan).

The berries were inoculated by spraying conidial suspensions three times without a surfactant (ca. $3.0 \times 10^{5}$ spores $/ \mathrm{mL}$ per ten berries) with an air brush sprayer (Fig. 2A). Inoculation was replicated twice per cultivar. A preliminary experiment indicated no differences in symptoms when $3.0 \times 10^{5}, 6.0 \times 10^{5}$, $1.0 \times 10^{6} \mathrm{spores} / \mathrm{mL}$ per ten berries were used. Inoculated berries were incubated at $25^{\circ} \mathrm{C}$ in the dark for 2 weeks, and the development of symptoms on berries was examined (Figs. 2B to 2D).

Juice was expressed from four berries from each cultivar on all sampling dates to determine the soluble solids content with a hand refractometer (N1, ATAGO, Japan) and titratable acidity (TA) by an electrochemical method with an Acilyzer model 5G (Fujihira, Japan).

\section{Results and Discussion}

This assay procedure affords a simple operation for elucidating rot resistance of ripe berries under nonaseptic experimental conditions, except for the preparation of the pathogen culture and its conidial suspensions. In preliminary tests, a spray of sterile water as control resulted in no symptoms on the berries, which indicated that the effect of latent infection with CA before berry sampling on the occurrence of lesions is negligible (data not shown).

The berries of five cultivars that were periodically taken and inoculated with CA (Fig. 3A) revealed no significant varietal differences in the percentage of diseased berries among samples taken from 30 to 50 days after full bloom. Ripe rot developed in $85 \%$ of the berries in 'Sunny Rouge' harvested 60 days after full

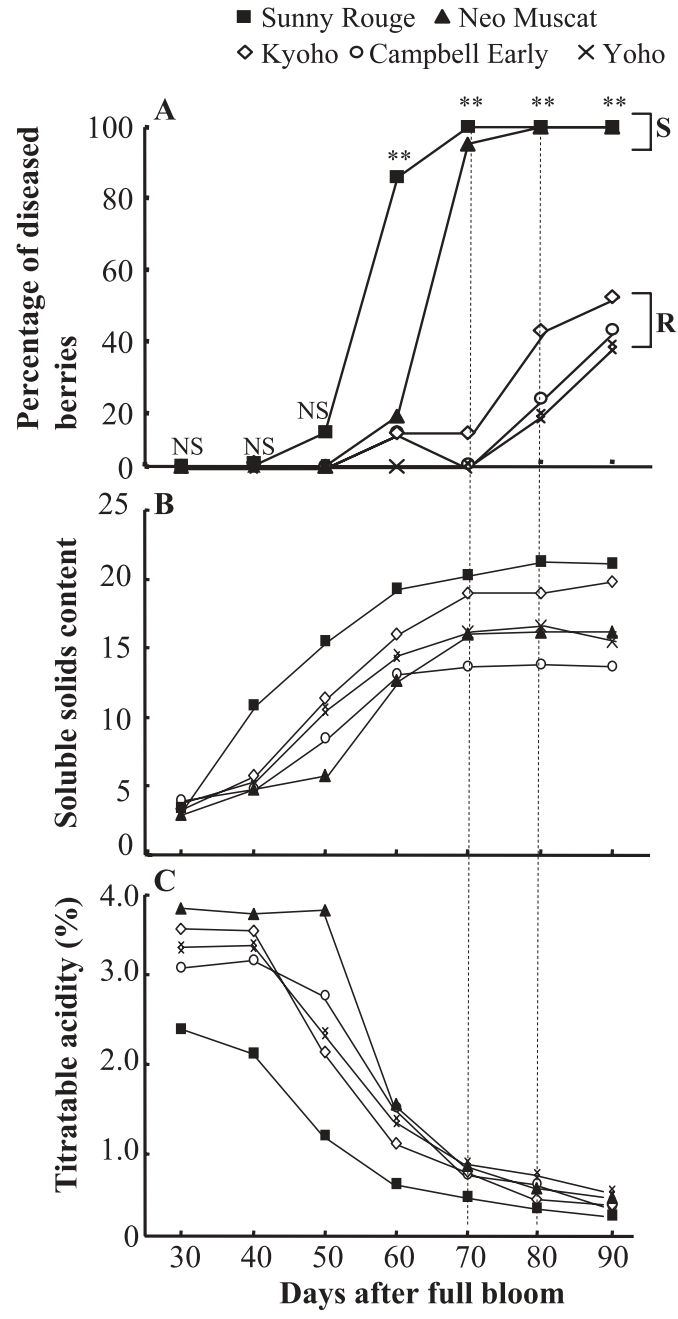

Fig. 3. Seasonal changes in the percentage of diseased berries with CA inoculation (A), the soluble solids content (B) and the titratable acidity (C) of grape berries periodically sampled from 30 days after full bloom. NS, **: Non significant or significant at $1 \%$ levels, respectively by one-factor ANOVA based on the arc-sin transformed data. S, susceptible cultivars; R, resistant cultivars.

bloom, whereas the disease infected other cultivars from 0 ('Campbell Early') to 15\% ('Neo Muscat'). Resistant ('Campbell Early', 'Kyoho', and 'Yoho') was discriminated at a significant level by using berries taken 70 to 80 days after full bloom. Although the difference in the percentages of diseased berries is significant, the inoculation at 90 days after full bloom tended to be less accurate because of the rapid increase in the diseased berries among the resistant cultivars. Berries harvested more than 90 days after full bloom withered and became unsuitable for the inoculation assay.

Soluble solids content (SSC) of the berries rapidly increased from 30 to 60 days after full bloom, and then slowly rose from 70 to 90 days after full bloom (Fig. 3B). Titratable acidity (TA) of the berries that were in a steady state between 30 and 40 days after full bloom (Fig. 3C) subsequently declined rapidly 40 to 60 days 
after full bloom when the berries in all cultivars attained veraison. Afterward, the acidity gradually diminished until harvest. In this study, rapid changes in chemical compositions in 'Sunny Rouge' occurred earlier than in the other cultivars because this cultivar was ready for harvesting commercially around 60 days after full bloom in 2004 (Fig. 3B, C). Harvest of other cultivars was delayed because of low SSC: 13.0 in 'Campbell Early' to 16.0 in 'Kyoho' or high TA: $1.12 \%$ in 'Kyoho' to $1.75 \%$ in 'Neo Muscat'. The average SSC and (TA) of all cultivars at 70 to 80 days after full bloom ranged from $17.0(0.75 \%)$ to $17.4(0.56 \%)$, which are consistent with the optimum time for beginning commercial harvest. This period coincides with the clear-cut separation of ripe rot resistance among the cultivars (Fig. 3A).

The percentage of diseased berries increased as the berries ripened in agreement with the earlier investigation by Ishii and Momose (1961). In practice, the outbreak of ripe rot near harvest results in a serious economic loss in grape production. The TA of berries at that state is generally below $0.8 \%$. Our results indicate that a period of 70 to 80 days after full bloom is suitable for berry sampling and subsequent $\mathrm{CA}$ inoculation to evaluate varietal differences in the ripe rot resistance of grapevine. However, for early-ripening grape cultivars such as 'Sunny Rouge', the assay should be done about
60 days after full bloom.

\section{Literature Cited}

Fukaya, M. 2001. Studies on etiology and control of grapevine ripe rot. I. Primary infection of grapevine ripe rot. Akita Fruit-Tree Exp. Sta. Bul. 27: 24-35 (In Japanese with English summary).

Fukaya, M. 2002. Differential sensitivity to iminoctadinetriacetate in two fungal pathogens of grape ripe rot. Ann. Phytopathol. Soc. Jpn. 68: 263-264 (Abstr. In Japanese).

Fukaya, M., H. Ishii and I. Takahashi. 1998. Dormant spray of benomyl for the control of grape ripe rot and detection of fungicide-resistant isolates of the fungus. Ann. Phytopathol. Soc. Jpn. 64: 394 (Abstr. In Japanese).

Ishii, K. and M. Momose. 1961. Studies on the control of grape ripe rot. Ann. Phytopathol. Soc. Jpn. 26: 217 (Abstr. In Japanese).

Ozoe, S., T. Takuda and T. Hirosawa. 1972. Studies on the etiology and the control of the ripe-rot of grapes. I. The primary occurrence of the disease and the chemical control in dormant period of grapes. Shimane Agr. Exp. Sta. Bul. 10: 120-158 (In Japanese with English summary).

Sonoda, R. M. and R. R. Pelosi. 1988. Outbreake of citrus postbloom fruit drop caused by Colletotricum gloeosporioides from lesions on citrus blooms in the Indian river of Florida. Proc. Florida State Hortic. Soc. Bul. 101: 3638.

\section{ブドウ晚腐病抵抗性の簡易検定法}

白石美樹夫 - 山田昌彦 - 三谷宣化 -上野俊人 - 中畧良二 ・ 中野正明

（独）農業・生物系特定産業技術研究機構果樹研究所ブドウ・カキ研究部 729-2494 東広島市安芸津町

\footnotetext{
晚腐病はブドウ収穫直前に発生する最重要病害であ る. 病原菌の Colletotrichum acutatum (CA) は, ベノミ ルおよびイミノクタジン酢酸塩薬剂に非感受性で殺菌剤 による防除効果を低減させる。本研究では, CA 菌抵抗 性の生食用ブドウ育種素材を選抜するための簡易検定法 を開発した．ブドゥ果粒を水洗・エタノール殺菌後，ポ リエチレンビニル袋に入れ, 10 果粒当たり約 $3.0 \times 10^{5}$ 個
}

$/ \mathrm{mL}$ 飞調整した胞子懸濁液を噴霧接種し, $25^{\circ} \mathrm{C}$ 暗黒下で 2 週間保持した。発病果率は, 果粒内の糖度の上昇と遊 離酸含量の低下に伴って上昇した．満開 70 日後から 80 日後の果粒を採取预よび接種した場合に抵抗性品種と感 受性品種の差異が明膫に生じた．以上の方法でブドゥ晚 腐病抵抗性を効率的に検定することが可能である。 